\title{
EFISIENSI MODAL KERJA DAN HUTANG PADA KINERJA PERDAGANGAN RETAIL DI INDONESIA
}

\author{
Rieke Pernamasari \\ Universitas Mercu Buana \\ rieke.pernamasari@mercubuana.ac.id \\ Sri Purwaningsih \\ Universitas Mercu Buana \\ sri.purwaningsih@mercubuana.ac.id
}

\begin{abstract}
Abstrak
Penelitian ini bertujuan untuk melihat efisiensi modal kerja yang diproksikan melalui perputaran kas, perputaran piutang, dan perputaran persediaan serta Hutang yang diproksikan melalui leverage terhadap kinerja perusahaan perdagangan retail yang diproksikan melalui return on asset pada tahun 2013 - 2017. Modal kerja dibutuhkan bagi perusahaan untuk membiayai kegiatan operasional sehari-hari, dimana modal kerja yang keluar diharapkan dapat kembali masuk dalam waktu yang pendek melalui hasil penjualan.Adanya modal kerja akan menjadikan perusahaan dapat memenuhi kewajiban jangka pendek yang berguna untuk menjalankan kegiatan operasional setiap hari. Sedangkan pada likuiditas, menunjukan kemampuan perusahaan untuk pemenuhan kewajiban.

Hasil penelitian ini menghasilkan bahwa modal kerja yang diproksikan melalui perputaran kas memiliki pengaruh negative terhadap kinerja perusahaan dan hutang yang diproksikan melalui return on asset memiliki pengaruh positif terhadap kinerja perusahaan. Sedangkan kedua variable modal kerja yang diproksikan melalui perputaran piutang dan perputaran persediaan tidak memiliki pengaruh pada kinerja perusahaan pada perdagangan retail di Indonesia.
\end{abstract}

Kata kunci: modal kerja, perputaran kas, perputaran piutang, perputaran persediaan, leverage, return on asset

\section{PENDAHULUAN}

Sebagai seorang agen, manajemen perusahaan mempunyai tugas dalam mengelola semua aktiva yang dimiliki oleh perusahaan secara efisien sehingga tercipta sarana dan prasarana penjualan.Seluruh komponen di dalam aktivitas perusahaan merupakan sumber daya (resources) yang harus dikelola sebagai sumber utama laba perusahaan.Oleh karena itu dibutuhkan pengelolaan yang tepat agar efisiensi dan efektivitas perusahaan tercapai.

Modal kerja dibutuhkan bagi perusahaan untuk membiayai kegiatan operasional sehari-hari, dimana modal kerja yang keluar diharapkan dapat kembali masuk dalam waktu yang pendek melalui hasil penjualan.Modal kerja juga sangat penting untuk menentukan tingkat likuiditas perusahaan, karena semakin baik dalam pengelolaan modal kerja maka semakin 
baik pula tingkat likuiditasnya. Adanya modal kerja akan menjadikan perusahaan dapat memenuhi kewajiban jangka pendek yang berguna untuk menjalankan kegiatan operasional setiap hari. Sedangkan pada likuiditas, menunjukan kemampuan perusahaan untuk pemenuhan kewajiban.

Nilmawati (2011) mengatakan dalam pengelolaan aktiva lancar (modal kerja), perusahaan menghadapi fundamental tradeoff antara modal kerja (likuiditas) dan laba (profitabilitas) yang dihasilkan. Semakin besar perusahaan menahan modal kerja maka makin kecil risiko kekurangan dana, dengan demikian menurunkan risiko operasi perusahaan, namun menahan modal kerja memerlukan biaya, misalnya jika persediaan terlalu besar maka perusahaan akan mempunyai aktiva yang menghasilkan pengembalian nol atau negative jika biaya penyimpanan dan kerusakan tinggi.

Ketidakakuratan mengelola komponen modal kerja akan mengakibatkan kesulitan dalam kelanjutan operasi perusahaan dan konsekuensinya adalah nilai pasar perusahaan akan jatuh. Seluruh komponen dari modal kerja seperti kas, piutang, persediaan serta hutang memiliki peran penting dalam kinerja perusahaan, (wulandari, 2015). Oleh karena itu tingkat efisiensi dari modal kerja ini dapat diukur dengan perputaran kas, perputaran persediaan, perputaran piutang dan nilai hutang terhadap profitabilitas perusahaan.Menurut Raheman \& Nashr (2007) untuk mencapai optimal manajemen modal kerja, manager perusahaan harus mampu mengontrol trade off antara memaksimumkan profitabilitas dan keakuratan likuiditas.Mengingat pentingnya modal kerja di dalam perusahaan, manajer keuangan harus dapat merencanakan dengan baik besarnya jumlah modal kerja yang tepat dan sesuai dengan kebutuhan perusahaan, karena jika terjadi kelebihan atau kekurangan dana hal ini akan mempengaruhi tingkat profitabilitas perusahaan (Supriyadi \& Fazriani, 2011).

Penelitian-penelitian yang mencoba menghubungkan antara modal kerja dengan kinerja telah banyak dilakukan namun masih belum sepenuhnya jelas.Nilmawati (2011) dalam penelitiannya menghasilkan variabel manajemen modal kerja yang diukur dengan menggunakan cash conversion cycle mempunyai pengaruh negatif signifikan terhadap kinerja perusahaan baik dengan menggunakan ukuran pasar (Tobin's Q) maupun dengan ukuran akuntansi (Gross Operation Profit/GOP).Wulandari menghasilkan modal kerja yang diproksikan dengan perputaran piutang 
memiliki pengaruh terhadap profitabilitas, sedangkan perputaran kas dan persediaan tidak memiliki pengaruhnya terhadap profitabilitas pada perusahaan pertambangan.

Penelitian ini mengambil objek perusahaan dalam bidang retail atau perusahaan dagang.Bisnis ritel sering memiliki siklus panjang karena mereka harus membeli inventori dalam jumlah besar dengan baik sebelum penjualan dilakukan. Hal ini terutama berlaku untuk operasi ritel batadan-mortir karena persediaan dalam jumlah besar seringkali diperlukan hanya untuk membuka toko, karena toko ritel jarang menjual semua inventaris mereka segera, mereka harus mempertahankan tingkat modal kerja yang lebih tinggi untuk memastikan bahwa mereka dapat memenuhi biaya jangka pendek tanpa mengandalkan pendapatan dari penjualan yang mungkin tidak akan sampai nanti.Sehingga permasalahan yang dapat diambil adalah apakah modal kerja yang diproksikan melalui perputaran kas, perputaran piutang, dan perputaran persediaan serta hutang yang diproksikan melalui leverage berpengaruh pada kinerja perusahaan yang diproksikan melalui profitabilitas return on asset.

\section{TINJAUAN PUSTAKA DAN PENGEMBANGAN HIPOTESIS}

\section{Signaling theory}

Brigham dan Houston (2011) menekankan pentingnya informasi yang dikeluarkan oleh perusahaan terhadap keputusan investasi pihak di luar perusahaan.Informasi merupakan unsur penting bagi investor dan pelaku bisnis.Dalam hal ini teori sinyal menjelaskan langkah-langkah manajemen dari perusahaan yang sebenernya memberikan petunjuk secara implisit kepada investor tentang bagaimana manajemen memandang prospek perusahaan.Pemberian sinyal juga dilakukan oleh manager untuk mengurangi asimetri informasi.Asimetri informasi ini dapat diminimalkan dengan mengungkapkan informasi sebanyakbanyaknya.Informasi yang diungkap diharapkan adalah informasi yang menunjukkan kondisi perusahaan yang sebenarnya.

\section{Modal Kerja}

Modal kerja merupakan salah satu unsur aktiva yang sangat penting dalam perusahaan karena tanpa modal kerja perusahaan tidak dapat memenuhi kebutuhan untuk menjalankan aktivitasnya. Menurut Kasmir (2013), modal kerja merupakan investasi yang ditanamkan 
dalam aktiva lancar atau aktiva jangka pendek seperti kas, bank, surat berharga, piutang, persediaan dan aktiva lancar lainnya. Munawir (2014) menyimpulkan bahwa modal kerja akan bertambah apabila adanya kenaikkan sektor modal baik yang berasal dari laba maupun adanya pengeluaran modal/saham investasi dari pemilik perusahaan, adanya pengurangan penurunan aktiva tetap yang diimbangi dengan bertambahnya aktiva lancar karena adanya penjualan aktiva tetap melalui proses depresiasi, dan adanya penambahan hutang jangka panjang baik dalam bentuk obligasi, hipotik atau hutang jangka panjang lainnya yang diimbangi dengan bertambahnya aktiva tetap.

Pada umumnya modal kerja bruto (gross working capital) yang sering dijumpai dalam perusahaan terdiri dari kas, piutang, dan persediaan.Perputaran kas yang semakin tinggi akan semakin baik, karena ini menunjukkan semakin efisensi didalam pengunaan kas. Perputaran kas yang berlebihan dengan modal kerja yang tesedia terlalu kecil, akan mengakibatkan kurang dapat memenuhi kebutuhan perusahaan, Menuh (2008). Rasio ini menunjukkan efektivitas manajemen dalam mengelola aset yang digunakan oleh perusahaan. Dengan menghitung tingkat perputaran kas akan dapat diketahui sampai sejauh mana tingkatefisiensi yang dapat dicapai perusahaan dalam mengelola kas untuk mencapai tujuan dari perusahaan itu sendiri.

Sedangkan jika tingkat perputaran piutang semakin besar maka dana yang dinvestasikan dalam piutang akan semakin kecil. Menurut Weygamdt et al (2013) periode perputaran piutang tergantung pada syarat pembayaran kreditnya, semakin lama syarat pembayaran kredit maka akan semakin lama pula piutang berputar. Terkait dengan resiko kepemilikan persediaan, dan fakta bahwa persediaanlebih lambat diubah menjadi kas dibanding piutang, persediaan biasanya dianggap aktiva lancar yang paling tidak likuid.Inventory turnover menunjukkan kemampuan-kemampuan dana yang tertanam dalam inventory berputar dalam suatu periode tertentu, atau likuiditas dari inventory dan pengukur untuk adanya overstock.Sehingga dibutuhkan konsistensi dalam penggunaan harga pokok penjualan sebagai pembilang karena, seperti juga persediaan, akun ini disajikan berdasarkan biaya perolehan, sedangkan persediaan rata-rata dihitung dengan menambah saldo awal dan akhir persediaan dan membaginya dengan dua, Kieso (2011).

\section{Hutang}

Dalam menjalankan kegiatan bisnisnya, perusahaan sering dihadapkan dengan pengeluaran biaya yang bersifat tetap. 
Yang tentu saja mengandung resiko. Berkaitan dengan itu pihak manajemen harus tau mengenai leverage. Dimana leverage mengandung biaya tetap dalam usaha yang menghasilkan keuntungan. Terdapat hubungan yang sangat erat antara leverage dengan struktur modal dan pembelanjaan. Dengan hadirnya leverage didalam struktur modal sebuah perusahaan menandakan bahwa perusahaan tersebut menghimpun dana dari luar perusahaan dengan harapan untuk meningkatkan laba perusahaan dikedepannya, Van (2002). Menurut Kasmir 2013, berdasarkan hasil pengukuran yang dilakukan, apabila besaran rasio utang terhadap aset adalah tinggi maka hal ini tentu saja akan mengurangi kemampuan perusahaan untuk memperoleh tambahan pinjaman dari kreditor karena dikhawatirkan bahwa perusahaan tidak mampu melunasi utangutangnya dengan total aset yang dimilikinya. Rasio yang kecil menunjukkann bahwa sedikitnya aset perusahaan yang dibiayai oleh utang.Standar pengukuran yang digunakan untuk menilai baik tidaknya suatu rasio perusahaan sebaiknya berdasarkan pada rasio rata-rata industri yang sejenis.

\section{Kinerja Perusahaan}

Di dalam teori akuntansi, Scott (2003) dalam utami (2015)adanya pendekatan konsep decision usefulness dan economic
consequences.Konsep decision usefullness berfokus pada pengguna laporan keuangan, sedangkan konsep economics consequences lebih melihat pada kepentingan atau perilaku manajer (manajemen). Manajemen mempunyai keinginan dan usaha (effort) untuk bekerja dengan baik, hal ini dilakukan agar ia mendapat kompensasi (imbalan) yang maksimum. Untuk mendapat kompensasi yang maksimum maka manager akan berusaha untuk menggunakan kebijakan akuntansi yang dapat memberikan dampak terbesar terhadap laba perusahaan, Utami (2007).Salah satu kinerja perusahaan dapat dilihat melalui kinerja keuangan.

Munawir (2014) menyatakan bahwa tujuan dari pengukuran kinerja keuangan perusahaan adalahmengetahui tingkat likuiditas, mengetahui tingkat solvabilitas, mengetahui tingkat profitabilitas, dan mengetahui tingkat stabilitas. Pengukuran rasio profitabilitas dapat dilakukan dengan membandingkan antara berbagai komponen yang ada di dalam laporan laba dan/atau neraca.Semakin tinggi ROA semakin tinggi kemampuan perusahaan untuk menghasilkan keuntungan. Semakin tinggi keuntungan yang dihasilkan perusahaan akan menjadikan investor tertarik akan nilai saham. Utami, (2015) dalam penelitiannya mengatakan terdapat hubungan positif antara hutang dengan 
tingkat kinerja keuangan yang diukur melalui profitabilitas.

\section{Hipotesis}

\section{H1 :Perputaran Kas berpengaruh pada Profitabilitas}

Kasmir (2013) mengatakan semakin tinggi perputaran kas ini akan semakin baik, karena hal menunjukkan semakin tinggi efisiensi penggunaan kas maka keuntungan yang diperoleh akan semakin besar. Deni (2014) dalam penelitiannya menghasilkan bahwa perputaran kas memiliki pengaruh terhadap ROA.

\section{H2: Perputaran Piutang berpengaruh pada Profitabilitas.}

Weygamdt et al (2013) periode perputaran piutang tergantung pada syarat pembayaran kreditnya, semakin lama syaratpembayaran kredit maka akan semakin lama pula piutang berputar. tingkat perputaran piutang semakin besar maka dana yang dinvestasikan dalam piutang akan semakin kecil. Surya (2017) dalam penelitiannya menghasilkan perputaran persediaan berpengaruh pada ROA.

\section{H3: Perputaran Persediaan}

berpengaruh pada Profitabilitas.

Menurut Horngren (2005) dalam wulandari (2015), Perputaran persediaan adalah rasio harga pokok penjualan terhadap persediaan rata-rata yang menunjukkan seberapa cepat persediaan tersebut dapat dijual.Intan (2012) dalam penelitiannya menghasilkan perputaran persediaan berpengaruh negative pada ROA.

\section{H4: Leverage berpengaruh pada \\ Profitabilitas.}

Sesuai dengan pecking order theory yang dikemukakan Myers dan Majluf (1984) dalam Harjito (2011), sebuah perusahaan cenderung akan menggunakan modal yang ada dalam perusahaan sebelum menerbitkan saham baru atau meminjam uang dari pihak luar. Sehingga sebuah perusahaan akan mempertahankan untuk memegang modalnya sendiri, untuk kebutuhan internal ataupun untuk membayar utang. Utang yang lebih banyak berarti modal internal yang dimiliki lebih sedikit untuk operasi perusahaan yang akan meningkatkan risiko perusahaan, sehingga rasio utang akan berpengaruh negatif terhadap nilai pasar. Nilmawati (2011) dalam penelitiannya menghasilkan leverage berpengaruh negative terhadapi profitabilitas.

\section{METODE PENELITIAN}

\section{Sampel}

Populasi penelitian ini adalah perusahaan perdagangan retail yang terdaftar di Bursa 
Efek Indonesia pada tahun 2013-2017. Adapun sampel diambil secara purposive sampling dengan kriteria: selama periode penelitian, perusahaan mempunyai laba positif dan bukan perusahaan sektor keuangan. Data yang digunakan dalam penelitian ini adalah data yang bersifat sekunder yaitu berupa laporan keuangan dan laporan kinerja perusahaan.Pengambilan sampel data memakai purposive sampling dimana penarikan sampel dilakukan berdasarkan kemampuan masing-masing anggota populasi dalam memenuhi informasi yang dibutuhkan oleh peneliti.Data-data tersebut dikumpulkan dari website www.idx.co.id.

\section{Definisi Variable}

Variabel Independen sering disebut sebagai variabel stimulus, predictor, antecedent., yakni variabel yang mempengaruhi atau yang menjadi sebab perubahannya atau timbulnya variabel dependen (Terikat) (Sugiyono,2013).Pada penelitian ini terdapat 4 variabel independen yaitu perputaran kas, perputaran piutang, perputaran persediaan, dan leverage.

Variabel dependen sering disebut sebagai variabel output, kriteria, konsekuen, yakni variabel yang dipengaruhi atau yang menjadi akibat, karena adanya variabel bebas. Pada penelitian ini variable dependen yang dipakai adalah return on asset (ROA).

\section{Table variable operasional}

\begin{tabular}{|c|c|c|}
\hline Variabel & Indikator & Skala \\
\hline \multirow{2}{*}{$\begin{array}{l}\text { Return On } \\
\text { Asset } \\
\text { (ROA) } \\
\text { Y }\end{array}$} & Laba Bersih Setelah pajak & \multirow[b]{2}{*}{ Rasio } \\
\hline & $\mathrm{ROA}=$ & \\
\hline $\begin{array}{l}\text { Perputaran } \\
\text { kas } \\
\text { X1 }\end{array}$ & $\begin{array}{l}\text { Perputaran Kas }=\frac{\text { Penjualan }}{\text { Rata-rata kas }} \\
\text { Rata-rata Kas }=\frac{\text { Kas awal }+ \text { Kas Akhir }}{2}\end{array}$ & Rasio \\
\hline $\begin{array}{l}\text { Perputaran } \\
\text { piutang } \\
\quad \mathbf{X}_{2}\end{array}$ & $\begin{array}{l}\text { Perputaran Piutang }=\frac{\text { Penjualan }}{\text { Rata-rata penjualan }} \\
\text { Rata-rata Piutang }= \\
\text { piutang awal }+ \text { piutang Akhir } \\
\frac{2}{2}\end{array}$ & Rasio \\
\hline $\begin{array}{l}\text { Perputaran } \\
\text { persediaan } \\
\quad \mathbf{X} \mathbf{3}\end{array}$ & $\begin{array}{l}\text { Perputaran Persediaan }= \\
\qquad \begin{array}{l}\text { Harga Pokok Penjualan } \\
\text { Rata-rata Persediaan }\end{array} \\
\text { Rata-rata Persediaan }= \\
\frac{\text { Persediaan awal + Persediaan Akhir }}{2}\end{array}$ & Rasio \\
\hline $\begin{array}{c}\text { Leverage } \\
\mathbf{X}_{4}\end{array}$ & $\begin{array}{l}\text { Debt to total asset ratio }= \\
\qquad \frac{\text { Total hutang }}{\text { Total Aktiva }}\end{array}$ & Rasio \\
\hline
\end{tabular}

Analisis Data

Untuk mencapai tujuan penelitian, pengujian dilakukan dengan menggunakan regresi linear berganda terhadap model berikut:

$\mathrm{PROF}=\alpha+\beta \mathrm{PK}+\beta \mathrm{PP}+\beta \mathrm{PR}+\beta \mathrm{LEV}+$ e

$$
\begin{array}{ll}
\mathrm{PROF} & =\text { Return on asset } \\
\mathrm{PK} & =\text { Perputaran kas } \\
\mathrm{PP} & =\text { Perputaran piutang } \\
\mathrm{PR} & =\text { Perputaran persediaan } \\
\mathrm{LEV} & =\text { Debt to total asset ratio } \\
\mathrm{e} & =\text { Error term }
\end{array}
$$

\section{HASIL PENELITIAN DAN PEMBAHASAN}

\section{Hasil}

Penelitian ini bertujuan untuk meneliti pengaruh modal kerja yang diproksikan melalui perputaran kas, perputaran piutang, 
dan perputaran persediaan serta hutang yang diproksikan melalui leverage terhadap kinerja perusahaan yang diproksikan melalui profitabilitas return on asset (ROA), dengan menggunakan sampel perusahaan retail di Bursa Efek Indonesia pada tahun 2013 - 2017. Table 1 merupakan ringkasan hasil uji regresi linier berganda yang menguji pengaruh pengaruh modal kerja yang diproksikan melalui perputaran kas, perputaran piutang, dan perputaran persediaan serta hutang yang diproksikan melalui leverage terhadap kinerja perusahaan yang diproksikan melalui profitabilitas return on asset (ROA). Dari table 1 dapat dibentuk persamaam berikut:

$\mathrm{PROF}=-155-330 \mathrm{PP}+104 \mathrm{PP}-246 \mathrm{PR}+$ 264LEV

Persamaan ini telah melewati asumsi klasik uji autokorelasi, multikolinearitas dan heteroskedastisitas.

Table 1 Ringkasan Hasil Uji Regresi Berganda dengan Variabel Dependen

\section{Tabel Uji t}

\begin{tabular}{lrrr} 
Variabel Independen & $\begin{array}{c}\text { Koefisien } \\
\text { Regresi }\end{array}$ & t & Sig. \\
(Constant) & -0.155 & -1.589 & 0.121 \\
perputaran_kas & -0.33 & -2.363 & 0.024 \\
perputaran_piutang & 0.104 & 0.786 & 0.437 \\
perputaran_persediaan & -0.246 & -1.713 & 0.095 \\
leverage & 0.264 & 2.025 & 0.05 \\
\hline F & 0.18 & & \\
R square & 0.191 & & \\
\hline Dependent Variable: Kinerja (ROA) & &
\end{tabular}
data olah: SPSS.22

Dari Tabel 1 diketahui bahwa secara bersama variabel modal kerja yang diukur dengan perputarn kas, perputaran piutang, perputaran persediaan, dan leverage secara simultan memiliki pengaruh terhadap variabel kinerja perusahaan yang menggunakan return on asset (ROA). Hal ini dikarenakan nilai $\mathrm{F}$ sebesar 0.18 lebih kecil dari tingkat signifikansi 0.05 . Sedangkan variabilitas dari variabel kinerja dapat dijelaskan sebesar $19.1 \%(\mathrm{R})$ oleh variabel modal kerja yang diproksikan melalui perputaran kas, perputaran piutang, dan perputaran persedian serta hutang yang diproksikan melalui leverage, sisanya dijelaskan oleh variabel lain di luar persamaan yang diajukan.

\section{Hasil Pengujian Hipotesis 1}

Hasil pengujian hipotesis dari penelitian ini menunjukkan nilai $\mathrm{t}$ untuk variabel Perputaran Kas sebesar -0.33 dengan nilai signifikansi sebesar 0,024 (dapat dilihat pada table 1), Sehingga dapat disimpulkan bahwa hasil penelitian dapat membuktikan bahwa Perputaran piutang memiliki 
pengaruh negatif signifikan terhadap kinerja perusahaan yang diproksikan melalui retusn on asset (ROA).Sehingga dapat disimpulkan hipotesis 1 diterima.

\section{Hasil Pengujian Hipotesis 2}

Hasil pengujian hipotesis dari penelitian ini menunjukkan nilai $t$ untuk variabel Perputaran persediaan sebesar 0.104 dengan nilai signifikansi sebesar 0,437 (dapat dilihat pada table 1), Sehingga dapat disimpulkan bahwa hasil penelitian tidak dapat membuktikan bahwa Perputaran piutang tidak memiliki pengaruh terhadap kinerja perusahaan yang diproksikan melalui retusn on asset (ROA).Sehingga dapat disimpulkan hipotesis 2 ditolak.

\section{Hasil Pengujian Hipotesis 3}

Hasil pengujian hipotesis dari penelitian ini menunjukkan nilai $\mathrm{t}$ untuk variabel Perputaran Kas sebesar -0.246 dengan nilai signifikansi sebesar 0,095 (dapat dilihat pada table 1), Sehingga dapat disimpulkan bahwa hasil penelitian tidak dapat membuktikan bahwa Perputaran persediaan tidak memiliki pengaruh terhadap kinerja perusahaan yang diproksikan melalui retusn on asset (ROA).Sehingga dapat disimpulkan hipotesis 3 ditolak.

\section{Hasil Pengujian Hipotesis 4}

Hasil pengujian hipotesis dari penelitian ini menunjukkan nilai $\mathrm{t}$ untuk variabel leverage sebesar 0.264 dengan nilai signifikansi sebesar 0,05 (dapat dilihat pada table 1), Sehingga dapat disimpulkan bahwa hasil penelitian dapat membuktikan bahwa leverage memiliki pengaruh positif terhadap kinerja perusahaan yang diproksikan melalui retusn on asset (ROA). Sehingga dapat disimpulkan hipotesis 4diterima.

\section{PEMBAHASAN}

\section{Pengaruh perputaran kas terhadap profitabilitas.}

Hasil uji t pada tabel 1 diperoleh perputaran kas berpengaruh negative signifikan terhadap kinerja perusahaan yang diproksikan melalui return on assetpada perusahaan perdagangan eceran selama periode 2013-2017. Angka negatif dapat diartikan bahwa perputaran kas yang tinggi menyebabkan rendahnya profitabilitas yang didapat.Hal ini dapat terjadi karena kas pada perusahaan perdagangan eceran lebih banyak digunakan untuk kepentingan lainnya seperti menutupi kerugian yang disebabkan karena adanya piutang tak tertagih, dan kas digunakan untuk pemeliharaan persediaan yang ada di gudang.

Hasil penelitian ini sejalan dengan Tejo (2015) dan Deni (2014) yang menyatakan bahwa berpengaruh negatif tersebut terjadi karena adanya kas yang 
digunakan untuk kepentingan lain seperti digunakan untuk menutupi kerugian yang disebabkan oleh adanya piutang tak tertagih, dan kas digunakan untuk pemeliharaan persediaan yang menumpuk digudang serta kas juga digunakan oleh pemilik modal.

\section{Pengaruh perputaran piutang terhadap} profitabilitas.

Hasil uji t pada tabel 1 di peroleh perputaran piutang tidak berpengaruh terhadap kinerja perusahaan yang diproksikan melalui return on asset pada perusahaan perdagangan eceran selama periode 2013-2016. Hal ini dapat dikatakan bahwa perusahaan perdagangan eceran kurang efektif dalam mengelola piutang perusahaan, atau waktu penagihan yang terlalu lama juga memiliki pengaruh yang besar pada perputaran piutang. Menurut Kamsir (2013) apabila piutang dikelola dengan efektif maka akan berdampak positif pada profitabilitas, karena semakin tinggi tingkat rasio perputaran piutang, maka semakin baik karena jumlah piutang tidak tertagih semakin sedikit serta tidak terjadinya over investment dalam piutang. Dengan begitu semakin cepat pula kas masuk bagi perusahaan dari penagihan piutang, sehingga kas dapat digunakan kembali untuk kegiatan operasional perusahaan, sehingga berdampak pada aktivitas penjualan serta profitabilitas akan meningkat.

Hasil ini sejalan dengan penelitian Ayu (2016) dan Budiansyah (2016), dimana karena periode perputaran piutang tergantung pada syarat pembayaran kreditnya.Semakin lama syarat pembayaran kredit makan akan semakin lama pula piutang berputar karena lamanya syarat pembayaran kredit sehingga kas yang diterima melambat dan akan mengganggu kegiatan operasional serta berdampak pula pada aktivitas operasional perusahaan.

\section{Pengaruh Perputaran persediaan terhadap profitabilitas.}

Hasil uji t pada tabel 1 diperoleh perputaran persediaan tidak berpengrauh signifikan signifikan terhadap kinerja perusahan yang diproksikan melalui return on asset padan perusahaan perdagangan eceran selama periode 2013-2017. Hal ini dapat dikatakan bahwa perusahaan perdagangan eceran kurang efektif dalam mengelola persediaan. Menurut kieso et al (2007) pada sarjito (2017) peningkatan persediaan menjadikan indikator akan terjadinya penurunan laba, disamping itu juga ketika perusahaan menghadapi penjualan yang lambat sementarapersediaan terus bertambah akan menambah biaya penyimpanan, resiko 
kerusakan tinggi dan juga adanya penurunan harga sehingga pengurangi pendapatan penjualan dan laba menjadi rendah.

Hasil ini sejalan dengan penelitian surya (2017), dan Ni Made (2014) yang mengatakan bahwa penyebabnya dikarenakan adanya investasi yang cukup besar di dalam persediaan yang tidak sesuai dengan kebutuhan dan menyebabkan besarnya biaya yang harus dikeluarkan untuk penyimpanan dan menanggung kerugian atas rusaknya persediaan yang ada di gudang.

Pengaruh debt to total asset ratio terhadap profitabilitas.

Hasil uji t pada tabel 1 diperoleh leverage berpengaruh signifikan terhadap kinerja perusahaan yang diproksikan melalui return on asset pada perusahaan perdagangan eceran selama periode 20132017. Hal ini dapat dikatakan bahwa terdapat hubungan yang sangat erat antara leverage dengan struktur modal dan pembelanjaan. Dengan hadirnya leverage didalam struktur modal sebuah perusahaan menandakan bahwa perusahaan tersebut menghimpun dana dari luar perusahaan dengan harapan untuk meningkatkan laba perusahaan dikedepannya, Van (2002)

Penelitian ini sesuai dengan hasil Nilmawati (2011) yang mengatakan hutang yang banyak berarti modal internal yang dimiliki perusahaan lebih besar untuk operasionalisasinya, sehingga potensi untuk meningkatkan laba lebih besar.

\section{SIMPULAN}

Berdasarkan analisis data yang diambil kesimpulan bahwa secara silmultan variable modal kerja yang diproksikan melalui perputaran kas, perputaran piutang, dan perputaran persediaan serta hutang yang diproksikan melalui leverage memiliki pengaruh terhadap kinerja perusahaan yang diproksikan melalui return on asset. Namun secara parsial, perputaran kas memiliki pengaruh negative dan leverage memiliki pengaruh positif terhadap kinerja perusahaan.

\section{KETERBATASAN DAN SARAN.}

Peneliti menyadari bahwa masih terdapat keterbatasan dalam penelitian ini, dan diharapkan untuk peneliti berikutnya agar dapat menambah variable moderating seperti good corporate governance.Bagi perusahaan sebaiknya lebih memperhatikan pengelolaan piutang dan persediaankarena hal tersebut memiliki satu kesatuan yang dapat mempengaruhi menurunkan unsur modal kerja. 


\section{DAFTAR PUSTAKA}

Agus,Sartono. (2012). Manajemen Keuangan Teori dan Aplikasi. Edisi Empat. BPFE: Yogyakarta

Agnes,Sawir . (2012).Analisis kinerja keuangan dan perencanaan keuangan perusahaan. Jakarta : Gramedia Pustaka Umum

Ayu,Putri. (2016). Pengaruh Perputaran Kas, Piutang, Persediaan terhadap profitabilitas pada Perusahaan Semen di BEI.Jurnal Sekolah Tinggi Ilmu Ekonomi Indonesia.

Berman, Barry and Evans, Joel R. (2001) . Retail Management. New Jersey: Prentice Hall Inc

Bramasto, Ari. (2008). Analisis Perputaran Aktiva Tetap dan Perputaran Piutang Kaitannya Terhadap Return on Assets pada PT POS Indonesia (persero) Bandung. Majalah Ilmiah UNIKOM. Vol 9. No. 2.

Brealey, R.A., Myes, S.C. 2003. Principles of Corporate Finance. $7^{\text {th }}$ Edition. New York: McGraw-Hill

Brigham, E. F. dan J. F. Houston. (2011) . Dasar - Dasar Manajemen Keuangan. Salemba Empat. Jakarta.

Deni,Irman. (2014). Pengaruh Tingkat Perputaran Kas, Perputaran Piutang dan Perputaran Persediaan terhadap Perusahaan Manufaktur yang Terdapat di Bursa Efek
Indonesia.Jurnal

Universitas

Maritim Raja Ali Haji.

Djarwanto PS, dan Subagyo, Pangestu. (2005). Analisa Laporan Keuangan. Edisi Kelima : Yogyakarta BPFE.

Ghozali.Imam (2015). Aplikasi Analisis Multivariate Dengan Program IBM SPSS 23. Semarang: Badan Penerbit Universitas Diponegoro.

Hendriksen, Eldon. S dan Van Breda, Micheal. (2002) . Teori Akuntansi. Edisi Kelima. Buku Dua. Penerbit Interaksara. Batam Centre.

Hery. (2016). Financial Ratio For Business. Grasindo: Jakarta

Hery. (2017). Analisis Laporan Keuangan Integrated and Comprehensive Edition. Grasindo: Jakarta

Intan, Putu dan Gede Merta. (2011) Pengaruh modal kerja terhadap profitabilitas perusahaan food and beverages. Jurnal Universitas Udayana Bali

Kasmir. (2015). Analisis Laporan Keuangan. Jakarta: PT Raja Grafindo Persada.

Kieso, D. E., Weygandt, J. J., \& Warfield, T. D (2011). Intermediate Accounting Volume 1 IFRS Edition. United States of America : WileyLevy, M. and Barton a. Weitz. (2001) . New York : McGraw-Hill 
Lukman. Syamsudin. (2004). Manajemen Keuangan Perusahaan, Edisi 8, Jakarta. PT. Raja Grafindo.

Marlina. (2015). Pengaruh financial leverage terhadap profitabilitas pada Perusahaan Sub Sektor Otomotif dan Komponen yang Terdaftar di Bursa Efek Indonesia. Jurnal Universitas Sriwijaya.

Murhadi, Werner R. (2013). Analisis Laporan Keuangan Proyeksi dan Valuasi Saham. Jakarta: Salemba Empat.

Musthafa. (2017). Manajemen Keuangan. CV Andi Offset : Yogyakarta

Nilmawati.(2011). Pengaruh Manajemen Modal Kerja pada Kinerja Perusahaan yang Terdaftar di Bursa Efek Indonesia.Karisma, Vol. 5 (3).

Raheman, A. \& Nashr, M. (2007). Working Capital Management and Profitability - Case of Pakistani Firms. International Review of Business Research Papers, 3 (2) Reni,Yuli. (2016). Pengaruh Leverage Keuangan terhadap Profitabilitas pada Perusahaan Manufaktur yang Terdaftar di BEI.Jurnal Sekolah Tinggi Ilmu Ekonomi Indonesia.

Restuti, Maria Immaculata. (2006) . Pengaruh Pertumbuhan Perusahaan Terhadap Peringkat Obligasi Dan
Yield Obligasi. Jurnal Akuntansi dan Keuangan, Volume 1 No 3, 2007.

Riyanto,Bambang. (2013) . dasar-dasar pembelanjaan perusahaan. Edisi Keempat. Yogyakarta: BPFE

Rudianto. 2012. Pengantar Akuntansi. Jakarta : Penerbit Erlangga

R, Werner dan murhadi. (2015). Analisis laporan keuangan proyeksi dan valuasi saham. Jakarta: salemba empat

Surya, Sarjito., Ruliana, Ruly.,\&Rosidi, Dedi. (2017). Pengaruh Perputaran Kas dan Perputaran Persediaan terhadap Profitabilitas.Akuntabilitas, Jurnal ilmu Akuntansi, Vol.10 No.2.

S,Munawir. (2014). Analisis Informasi Keuangan. Liberty: Yogyakarta

Setyawati, Ari. (2014). Pengaruh Karakteristik Rasio Finansial dan Faktor Makroekonomi terhadap Return On Asset Bank Komersial.Diponegoro Journal of accounting, Vol 3 No.3

Sugiyono. (2013) . Metode penelitian manajemen. Alfabeta: Bandung

Sutrisno. (2009). Manajemen Keuangan Teori, Konsep dan Aplikasi, Edisi Pertama, Cetakan Ketujuh. Ekonisia: Yogyakarta. 
Sofyan Syafri Harahap. (2011) . Analisa Kritis atas Laporan Keuangan, Edisi ke-5, Jakarta: Raja Grafindo Persada. Tejo,Mohamad. (2014). Pengaruh Perputaran Persediaan, Perputaran Piutang, dan Perputaran Kas terhadap Profitabilitas pada Perusahaan Sektor Industri Barang Konsumsi yang Terdaftar di Bursa Efek Indonesia Periode 2008 - 2013. E-Journal, Universitas Pandanaran Utami, wiwik. (2007). Kajian Empiris hubungan kinerja lingkungan, kinerja keuangan dan kinerja pasar: model persamaan struktural. The $1^{\text {st }}$ accounting conference university of Indonesia.

Utami, wiwik. (2015). Financial performance and the quality of sustainability disclosure based on global reporting initiative: value relevances study in indonesia stock exchange.

Veronika, Ni Made., Budiasih, IG AN (2014).Pengaruh Debt to Equity Ratio, Firm Size, Inventory Turn Over dan Asset Turnover pada Profitabilitas.E-Jurnal Akuntansi Universitas Udayana Vol 6 No.2. ISSN: 2302-8556

Wulandari, Geby. (2015). Pengaruh modal kerja terhadap profitabilitas pada perusahaan pertambangan yang terdaftar di Bursa Efek Indonesia. JOM FEKON, Vol. 2 No. 1

Warren D. Carl, dkk. 2013. Pengantar Akuntansi, Buku I. Jakarta: Salemba Empat.

Wijaya. David. (2017). Manajemen keuangan konsep dan penerapananya. Grasindo: Jakarta

Supriyadi, Yoyon., Fazriani, Fani. (2011). Pengaruh Modal Kerja Terhadap Tingkat Likuiditas dan Profitabilitas. Jurnal Ilmiah Ranggagading. Volume 11 No. 1. 